
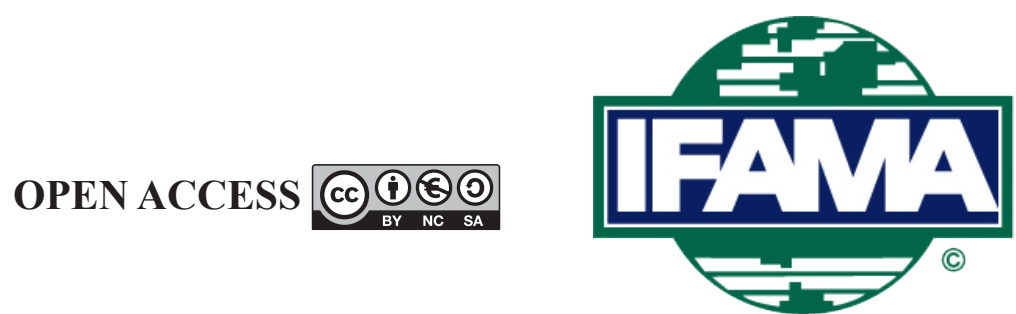

International Food and Agribusiness Management Review

Volume 24, Issue 6, 2021; DOI: 10.22434/IFAMR2020.0177

18 October 2020 / Accepted: 25 January 2021

Special Issue: IFAMA 2020 Symposium

Received: 18 October 2020 / Accepted: 25 January 2021

\title{
Performance and informality: the key to sustainability in small scale agrifood systems RESEARCH ARTICLE
}

\author{
Kim P. Bryceson ${ }^{\circledR a}$ and Anne Ross ${ }^{\mathrm{b}}$ \\ aProfessor of Agribusiness Technologies, School of Agriculture and Food Science, \\ The University of Queensland, Brisbane, QLD 4072, Australia. \\ ${ }^{b}$ Honorary Associate Professor, School of Social Sciences, \\ The University of Queensland, Brisbane, QLD 4072, Australia
}

\begin{abstract}
In small scale societies and developing nations, agrifood systems tend to be structurally less complex than in developed nations but have a complexity introduced in the form of strict social and cultural mores which both help to formulate decision making and create governance mechanisms. Informality in the economic underpinning of these agrifood systems has worked for these small-scale societies for thousands of years but the question is whether and how they can remain sustainable in the fast moving change situation of today's global business. In this paper we discuss sustainability from a modified Triple Bottom Line perspective and analyse data from horticultural product chain studies in two Pacific Island countries to investigate the informal framework of sustainability in these systems. We use the theoretical paradigm of theatre performance (frontstage:backstage) to understand how a 'habitus of informality' is both a threat and an opportunity to sustainability in these small scale, yet complex, systems.
\end{abstract}

Keywords: agrifood complex systems, habitus of informality, backstage frontstage performance JEL code: Q1, Q13, Q5, Q56

\footnotetext{
(1)Corresponding author: k.bryceson@uq.edu.au
} 


\section{Introduction}

Agrifood systems are structurally complex (Bryceson and Smith, 2008; Surana et al., 2005; Thompson et al., 2007). In developed countries they involve multiple firms usually working together within specific food industry sectors to satisfy an increasingly globalised market demand for high value food products (Catteneo, 2013; Harland, 1996; Ravenhill, 2014; Underhill et al., 2010). The requirement for globalised inter-organisational and intra-organisational decision-making to address the process of adding value to a raw commodity product through different stages of the agrifood chain, adds to the complexity. The simultaneous economic, political and environmental issues of the day that impact randomly and unpredictably on decision making in every component of the chain also adds to the complexity (Cao et al., 2019; Ericksen, 2008; Gamboa et al., 2016). Additionally, the agrifood sector is often referred to as a 'food system' that encompasses biological, economic, social, health and political systems at different scales and this introduces yet more complexity (Béné et al., 2019; Binder et al., 2010; Ingram, 2011). In adding 'sustainability' into this mix, a further layer of complexity is introduced, with an ever-widening circle of potentially unintended outcomes (Peano et al., 2015).

In small-scale societies and developing nations, agrifood systems tend to be structurally less complex than in developed countries, but have complexity introduced in the form of strict social and cultural mores (Elayah, 2016; Susomrith and Suseno, 2017; Vorley, 2013). These elements help to formulate decision making and create governance mechanisms. Informality in the economic structures of these agrifood systems has worked for these small-scale societies for thousands of years - and thus by any metric they have been 'sustainable' (Peano et al., 2015) - but the question is whether and how they can remain so in the fast-moving change situation of today's global business?

In managing different agrifood system complexities, business approaches and processes between developing and developed societies differ substantially. In developed countries, business processes are based on formalised economic and demand-driven supply and value chain systems with value-added products and specialised producers and specialised traders. In these economies, resources and financial sustainability are key concepts. It is often implied in the literature that this economic approach applies globally - in both developed and developing economies (see critiques by Eyben, 2005; Haque, 2018; Viswanathan et al., 2012; Vorley, 2013). However, in social sciences discourse, small-scale and developing societies are recognised as being unfamiliar with sophisticated trading frameworks, operating instead in economic systems that emphasise subsistence production, informal exchange relationships and socio-culturally driven livelihoods (e.g. Bourdieu, 1986; Hoffstaedetter and Roche, 2011) with little or no specialisation. In these societies, a 'habitus of informality' frames economic and social systems (Bryceson and Ross, 2019) where 'habitus' (Bourdieu, 1977) defines the ongoing and repeated social practices of the community that are built around social phenomena such as religious affiliation, kinship, local economic activity and community structures generally.

Recent work by Ram et al. (2017), Ross and Bryceson (2019) and Susomrith and Suseno (2017), has provided evidence to show that the intangible, informal socio-cultural phenomena that provide the economic and social frameworks for small-scale societies are actually quite formalised. Moreover, they underpin the sustainability of the overall societal system in the long term, as well as providing an ability for the society to respond to short term shocks (Balbo et al., 2016; Smith et al., 2016; Tendall et al., 2015), despite the complexities involved (Bryceson and Ross, 2019).

Sustainability per se as a term is difficult to define (Lélé, 1991), and the terminology has been caught up in the concept of sustainable development (Brundtland, 1987), which itself is defined as '[economic] development that meets the needs of the present without compromising the ability of future generations to meet their own needs'. In this paper we take the simplest definition as a starting point, which is that sustainability means 'a process or state [that has] the ability to continue or be continued for a long time' (Oxford Dictionary, 2020). 
There are a number of approaches to sustainability in the food and agribusiness sector: one is the approach taken by many medium to large modern organisations, which tends to have an emphasis on corporate metrics that address corporate social responsibility goals (e.g. Garriga and Mele, 2004; McGuire et al., 1988). Another approach is the Triple Bottom Line (TBL) model, suggested by Elkington (1994), which is a way of looking at sustainability from a 'people, planet, profits' perspective and using social, environmental and financial metrics derived from information held within the organisation to quantify it. Unfortunately, as Elkington (2018) identifies, in most instances where a TBL approach has been used, the economic aspect has had a greater importance than the environment and social aspects. Figure 1 illustrates this approach and identifies some possible indicators that can be used for developing metrics for analysis.

As well as understanding the economic and social structures that underpin livelihood and sustainability in small scale societies, the concept of 'performance' is an important one to investigate (Hoffstaedter and Roche, 2011: 534; Mosse, 2013; Reenberg et al., 2008; Ross and Bryceson, 2019). Goffman (1959: 94) argued that all social activity can be conceived as 'performance' and that all outward, or public performance presented by an individual, or by an entire community, is a 'front' (Goffman, 1959: 85). He also recognised that there is a 'backstage' performance, where actors refine their 'act' away from the audience view (Goffman 1959: 124). This idea of performance, we contend, is a significant aspect in small scale society local agrifood chains and potentially on their sustainability.

An example of this frontstage:backstage performance can be seen in many aspects of international aid to developing countries. Hoffstaedter and Roche (2011) argue that in designing international aid packages for development and change, both aid donors and aid recipients tend to 'perform' to each other to ensure that certain expectations of practice are met. For the donors, their performance is based on a perception that formal governance structures need to be built in recipient countries to encourage uptake of modern market systems. For the beneficiaries of aid, their performance is designed to advertise to the international aid agencies and

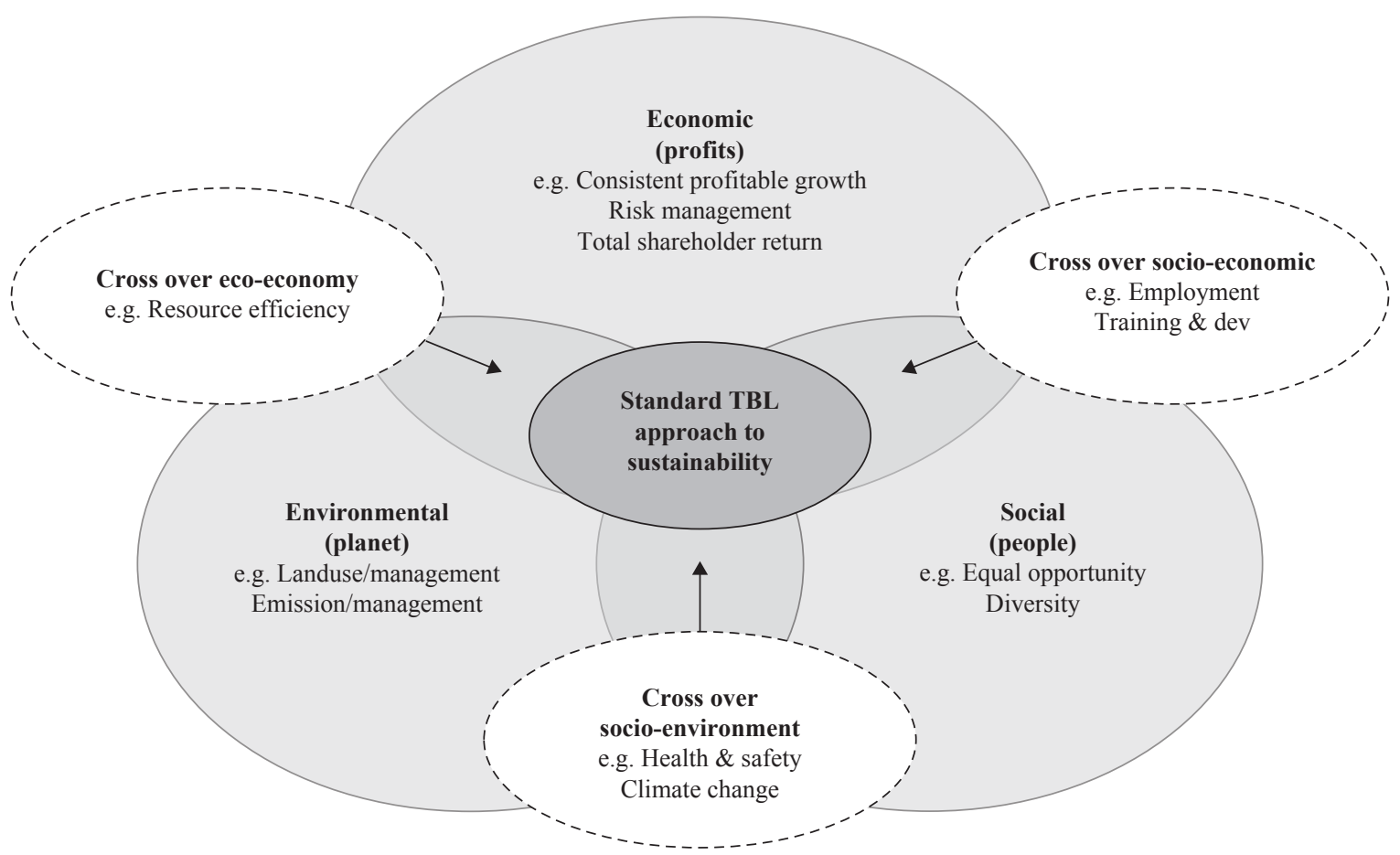

Figure 1. Standard triple bottom line (TBL) approach where social (people), environment (planet) and economics (profits) are represented as being of 'equal' importance, but where in reality the economic component takes precedence (Elkington, 2018). The 'crossover bubbles' have been added over time as people have adapted the approach. 
their sponsoring countries that, as potential recipients of aid, they are capable of implementing the changes upon which the proffered aid is predicated. These 'frontstage' performances, however, especially those at the village level where on-the-ground livelihood improvement is so desired, often hide a deeply different 'backstage' reality.

In 2019, Bryceson and Ross reported on a project where the data collected in two Pacific Island Countries (Tonga and Solomon Islands) were used to investigate whether a modus operandi of informality in the agrifood chains of these small-scale societies can 'fit' with the changes in how businesses are currently being run. Ross and Bryceson (2019) then used the trope of the habitus of informality and the theoretical paradigm of the role of performance in aid offerings and acceptances, to discuss the problems that result from a top-down approach to aid-giving. Ross and Bryceson demonstrated that much aid fails to recognise and acknowledge the essential imperative of the socio-cultural / socio- economic frameworks that underpin small scale societies and thus their sustainability.

In this paper we further develop our thesis on the role of habitus when we look at that same data, but through a lens of 'sustainability', with the aim of investigating how small-scale societies, with their habitus of informality, perform in relation to sustainability impositions. We ask the question: 'Can the subsistence scale supply chains found in many developing nations be expanded beyond the local level to provide capacity and opportunities in a sustainable manner - and if so how?

\section{Methods}

A case study approach (Yin, 2003) was used to investigate the questions: 'How can a modus operandi of informality 'fit' with the changes needed to join the sophisticated, formal market systems of a sustainable global agrifood sector? How do they perform?' and 'Can subsistence scale supply chains found in many developing nations be expanded beyond the local level to provide capacity and opportunities in a sustainable manner - and if so how?'

Horticultural product chains in two South Pacific nations (Tonga and Solomon Islands) were studied to address the informal/formal dichotomy associated with 'doing business' in small-scale societies, and to investigate the influences of 'frontstage' and 'backstage' performances on potential development.

\subsection{Case study protocol}

The protocol used for this study is described in Bryceson and Ross (2019), but is briefly reviewed here for completeness. The key methods employed to obtain data were: participant observation, to identify consequences of externally introduced agricultural and market intervention activities; and semi-structured interviews based on questions developed using the Hybrid Value Chain Framework (HVCF). The HVCF is discussed in detail in Bryceson and Ross (2019), but displayed in an abbreviated form in Table 1. This framework is used to document food security needs, agrifood production, market access, and supply chain knowledge. Free-listing exercises were incorporated into the interviews to encourage participants to provide answers to open-ended questions about food production, income needs, market opportunities.

Data collection took place over a 12-month period with two 10-day field trips being made to each country on two separate occasions. Seventy-four people from 12 villages across the islands of Tongatapu, 'Eua and Vava'u in Tonga, and 80 people from five villages on Guadalcanal and seven villages in Marovo Lagoon (Western Province), Solomon Islands, were interviewed to determine the nature of their agricultural production and market participation. 
Table 1. The Hybrid Value Chain Framework (summarised from Bryceson and Ross, 2019).

\begin{tabular}{|c|c|c|}
\hline \multirow[b]{2}{*}{ Aspect of the chain } & \multicolumn{2}{|l|}{ What to find out } \\
\hline & Standard market value chain approach & Community/livelihood value chain approach \\
\hline $\begin{array}{l}\text { Business enabling } \\
\text { environment }\end{array}$ & $\begin{array}{l}\text { Social, economic \& political } \\
\text { - Corporate, business strategies; } \\
\text { enterprise management processes }\end{array}$ & $\begin{array}{l}\text { Social, economic \& political } \\
\text { • Worldview (community, cultural \& spiritual) }\end{array}$ \\
\hline $\begin{array}{l}\text { 1. Industry } \\
\text { stakeholders \& } \\
\text { activities }\end{array}$ & $\begin{array}{l}\text { Stakeholders involved in the chain } \\
\text { - Formal elements of chain }\end{array}$ & $\begin{array}{l}\text { Stakeholders involved in the chain } \\
\text { - Community structure of chain } \\
\text { - Non-market transactions }\end{array}$ \\
\hline $\begin{array}{l}\text { 2. Product creation \& } \\
\text { delivery }\end{array}$ & $\begin{array}{l}\text { Product/s? } \\
\text { - Transport and logistics } \\
\text { - Quality attributes } \\
\text { - Managing supply chain flexibility }\end{array}$ & $\begin{array}{l}\text { Product/s? } \\
\text { - What and availability } \\
\text { - Attitude to quality } \\
\text { - End market }\end{array}$ \\
\hline 3. Financial conditions & $\begin{array}{l}\text { Costs and values } \\
\text { - Financial performance }\end{array}$ & $\begin{array}{l}\text { Costs and values } \\
\text { - Exchange and barter } \\
\text { - Intrinsic value of products to community/ } \\
\text { culture }\end{array}$ \\
\hline $\begin{array}{l}\text { 4. Information } \\
\text { conditions }\end{array}$ & $\begin{array}{l}\text { Information flows and risks across chain } \\
\text { - Business risks/risk dynamics }\end{array}$ & $\begin{array}{l}\text { Information flows and risks across chain } \\
\text { - Knowledge sharing } \\
\text { - Effect of culture on communication }\end{array}$ \\
\hline $\begin{array}{l}\text { 5. Incentives, } \\
\text { motivators and } \\
\text { drivers }\end{array}$ & $\begin{array}{l}\text { What systems? } \\
\text { - Price premiums } \\
\text { - Contracts/ loan guarantees }\end{array}$ & $\begin{array}{l}\text { What systems? } \\
\text { - Market incentives } \\
\text { - Community/livelihood incentives }\end{array}$ \\
\hline $\begin{array}{l}\text { 6. Governance } \\
\text { conditions }\end{array}$ & $\begin{array}{l}\text { Power and control } \\
\text { - Contracts } \\
\text { - Strategic alliances }\end{array}$ & $\begin{array}{l}\text { Power and control } \\
\text { - Community power dynamics } \\
\text { - Social norms }\end{array}$ \\
\hline
\end{tabular}

Participants included local growers and local sellers at the village level, specifically: people from 'rural and remote' villages that were more than $20 \mathrm{~km}$ from main markets; people from 'peri-urban' villages, defined here as those within $10 \mathrm{~km}$ of main markets; and people from 'urban' villages and towns, situated within $5 \mathrm{~km}$ of the main markets. Interviewees from villages were chosen with the assistance of local gatekeepers and via the technique of 'snowballing', which uses the contacts of interviewees to expand the sample. The full interview protocol has been published by Bryceson and Ross (2019) and included translating the questionnaire into Tongan and into Solomon Island pijin to facilitate interviewee understanding. Participant observations occurred daily for up to a week at a time at the local, regional and national markets and the average length of an interview conducted was approximately 30 minutes.

The data collected were validated using the standard methodological technique of triangulation. In this case, the data were accepted as robust and reliable when patterns (of both similarity and difference) were identified across all the interview participants, both local villagers and townsfolk, and when interview narratives aligned with anthropological baseline data (see Ross and Bryceson (2019) for details).

Data were analysed both quantitatively (descriptive statistics where appropriate), and qualitatively (manual thematic analysis of interview transcripts). For recording of the latter and for discussion purposes, the results of these analyses were presented in a qualitative form as individual tables for each of the six 'aspects of chain' defined in the HVCF template (Table 1). Each table identified the aspect in column 1 and the associated linked questions in the HVCF column 2 (standard market value chain) and column 3 (community- hybrid value chain). As such, these series of tables enabled detailed data recording and comparison across the two forms of chain analyses. An example of how the data were recorded for Aspect 1 (business environment, industry stakeholders and activities) is shown in Table 2. 
Table 2. An example of how the interview data were recorded and analysed in relation to the local agrifood chain analyses using Aspect 1 of the Hybrid Value Chain Framework (Bryceson and Ross, 2019). ${ }^{1}$

\begin{tabular}{|c|c|c|c|}
\hline \multirow{2}{*}{ 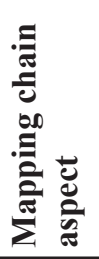 } & \multirow[b]{2}{*}{ : } & \multicolumn{2}{|l|}{ Tasks } \\
\hline & & $\begin{array}{l}\text { Standard market value chain analysis } \\
\text { (column 3) }\end{array}$ & $\begin{array}{l}\text { Community/livelihood value chain analysis (hybrid } \\
\text { economy) } \\
\text { (column } 4 \text { ) }\end{array}$ \\
\hline 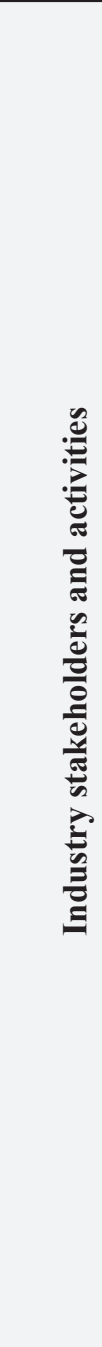 & 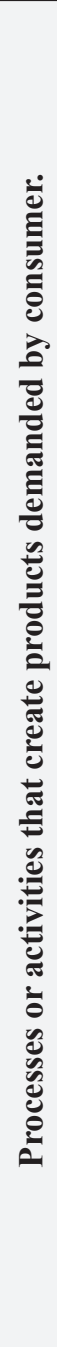 & $\begin{array}{l}\text { Stakeholders/groups involved } \\
\text { - Inputs (suppliers) } \\
\text { - Only one or two companies in Tonga, } \\
\text { none in SI. } \\
\text { - Production } \\
\text { - Subsistence production drives } \\
\text { livelihood and market processes at } \\
\text { village level. } \\
\text { - Some specialised production for export } \\
\text { from Tonga (e.g. taro, cassava, squash } \\
\text { and vanilla). } \\
\text { - Processing } \\
\text { - None at village/local levels. } \\
\text { - Distributors } \\
\text { - None at village/local levels. } \\
\text { - Retailing } \\
\text { - Small village and local roadside } \\
\text { markets. } \\
\text { - Trade stores (up to 50\% mark up on } \\
\text { processed produce). } \\
\text { - One central market in capital city. } \\
\text { - Shops and cafes in main towns and } \\
\text { cities. } \\
\text { - Resorts and eco-lodges. } \\
\text { - Defence force and hospital in Tonga. } \\
\text { - Limited/no supermarket outlets. } \\
\text { - Consumer (demand) } \\
\text { - Local individuals according to need; } \\
\text { retailers/resorts/cafes in towns and } \\
\text { - }\end{array}$ & $\begin{array}{l}\text { Stakeholders/groups/community involved } \\
\text { - Informal economy } \\
\text { - Domestic/locally based non-registered businesses. } \\
\text { - Non-market transactions and associated stakeholders } \\
\text { - Land tenure - hereditary and genealogical governance } \\
\text { issues. } \\
\text { - Responsibilities to family, church (tithing and imposts } \\
\text { on ability to work on Sabbath). } \\
\text { - Intra- and inter- village obligations. } \\
\text { - Sleeping at markets to avoid transport costs in SI. } \\
\text { - Lack of health and sanitary infrastructure at markets } \\
\text { (particularly problematic at larger town/city markets). } \\
\text { - Time needed for several weekly (even daily) community } \\
\text { and social activities. } \\
\text { - Relationships between stakeholders? } \\
\text { - Social relationships largely kin-based; cultural activities } \\
\text { often based around church. } \\
\text { - Tensions between church participants and 'backsliders' } \\
\text { impact on markets and work at resorts in SI. } \\
\text { - Tension between Chinese producers and market stall } \\
\text { holders in Tonga. } \\
\text { - Who are the consumers? } \\
\text { - Local buyers buy what is available at market. } \\
\text { - No concept of demand amongst either producers or } \\
\text { consumers. } \\
\text { - In main towns/cities, consumers include shop owners, } \\
\text { hotel managers, who access markets for specific } \\
\text { product; large consumers (army, hospital) may issue } \\
\text { - } \text {. }\end{array}$ \\
\hline
\end{tabular}

${ }^{1} \mathrm{SI}=$ Solomon Islands.

\section{Results}

A detailed presentation of results from the mixed method approach employed in this project can be found in Bryceson and Ross (2019) and in Ross and Bryceson (2019) and will not be repeated here. However, in summary: mapping the horticultural chains in both countries showed them to be quite simple in terms of structure, and each had a strong emphasis on informality. There is a complex intersection of social, cultural, political and economic elements that exist in both countries and Church and the Community dominates all aspects of the chain. There is a clear habitus of informality in 'doing business', which has created the foundation for the current sustainable agrifood market systems found in each country. Figure 2 diagrammatically illustrates the complex intersection of social, cultural, political and economic elements that exist in Tonga and Solomon Islands. 


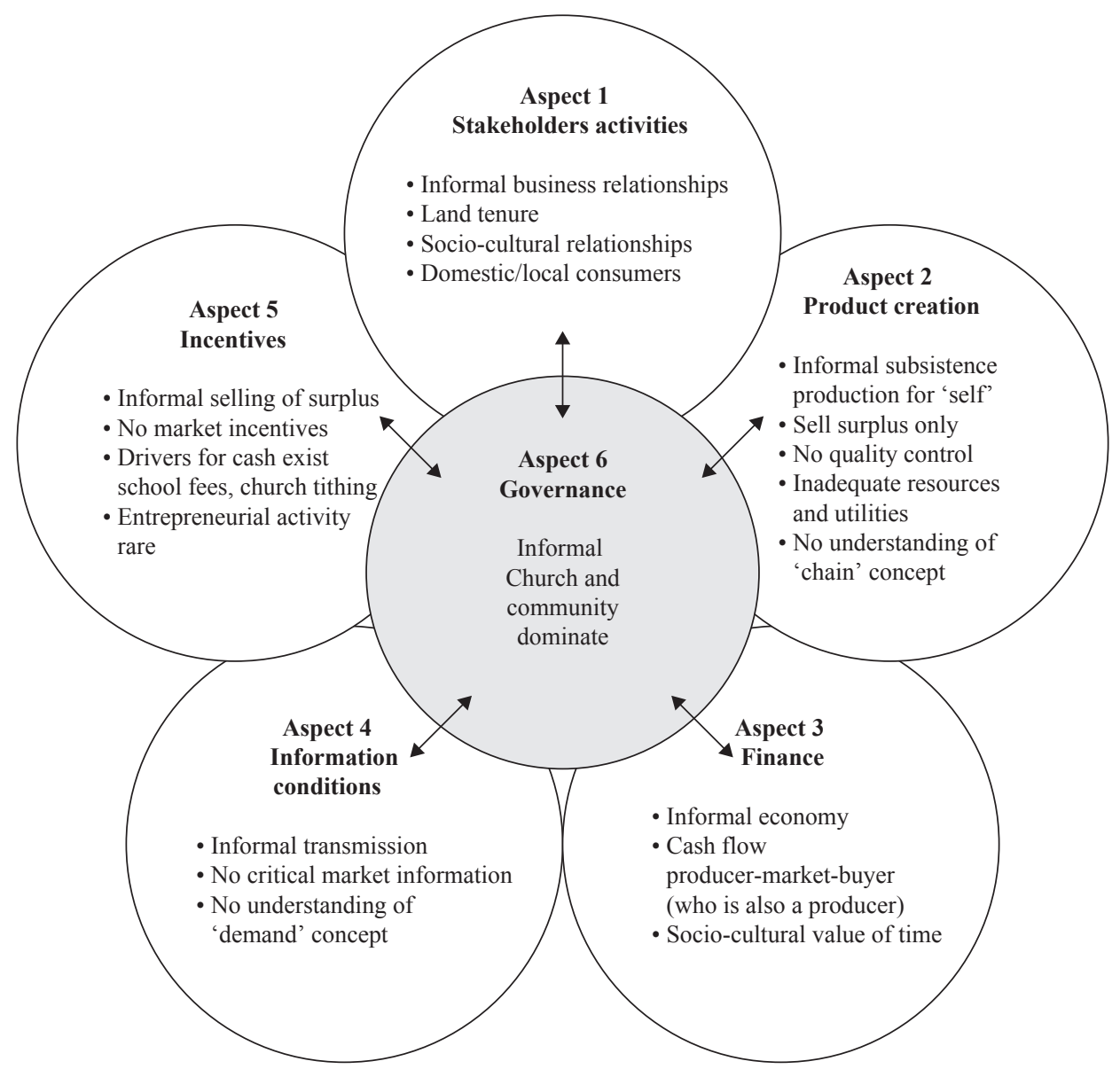

Figure 2. The complex intersection of social, cultural, political and economic elements that exist in Tonga and Solomon Islands in 'doing business' in Tonga and Solomon Islands.

The internal and external issues that impact on the businesses in these agrifood chains can be discussed generally from a social, economic and political perspective - and more specifically, from a strategies, people and process standpoint, to answer the underpinning research questions in this paper. That is: 'How do small-scale societies, with their habitus of informality, perform in relation to sustainability impositions by external forces such as international aid organisations', and 'Can subsistence scale supply chains found in many developing nations be expanded beyond the local level to provide capacity and opportunities in a sustainable manner - and if so how?'

The analyses of the results for each aspect (Table 1) to address this question, are summarised below.

\section{Aspect 1: Stakeholder activities}

Gardening and subsistence agriculture dominate production. Only when certain crops were in oversupply did the gardener turn to a market to make a sale. As a consequence, the 'stakeholders' in small-scale societies are family members or other villagers rather than market clients, or contractors. Indeed, there were virtually no contractors in any of the villages within which the study took place. Supply into the markets was dependent upon whether or not production was superfluous to family needs. Results thus emphasised the roles of kin, rather than clients or producers, and a sustainable supply chain was one that ensured social well-being ahead of economic viability. 


\section{- Aspect 2: Product creation}

Product creation in every village studied was based upon the importance of subsistence gardening rather than commercial crop production. There was an overt emphasis on providing whatever can be grown in quantities to fulfil family and church obligations - producers only going to the market when everyone in the village had enough to eat. What was being sustained, by this dictum, was the community, rather than any business.

\section{Aspect 3: Finance}

Here our results demonstrated that cash flow from the producer-market-buyer (who is almost always one and the same person) is key - and monetary obligations are entirely to church and state (especially schools). There is also a social value attributed to time that cannot be monetised. Furthermore, food markets were only one mechanism used by people to raise the funds they needed: some families worked together and shared resources such as their canoes or vehicles, others made crafts (carvings, hats, bags, jewellery) for sale to tourists. Once again, the results indicate that informality is designed to sustain the community, rather than generate any significant economic outcome.

\section{Aspect 4: Information conditions}

There is very little information exchange associated with market activity in the communities studied for this project. As an example of this, there is very little demand for a specific product - what gets sold is what is available. Where information did become important was at the village level to discuss the food needs of church festivals or to plan for family events. Nevertheless, many interviewees preformed a 'demand (for product) narrative' for the researchers. Sellers told stories of their ability to meet buyer demand, offered to the researchers as affirmation of the respondents' sophistication as sellers. These interviewees were presenting a frontstage enactment of formal marketing worldliness. But the backstage reality, observed through ethnographic observation and engagement with the community generally, was that no one first ascertained product type and quantity at a market before embarking on their own sales journey, as claimed. As a consequence, markets were always dominated by an oversupply of produce that was shared by all gardeners. Once again, the informality paradigm in doing business supports the society, rather than the economics of the market.

\section{- Aspect 5: Incentives}

The results of data collected for this aspect indicated that the market authority (whether that be the church or a city authority) set market prices based on product quantity, not quality. There are no incentives such as premium pricing or contracts, and no drivers such as demand - the only incentive to sell at markets is to pay school fees, church tithes, or to buy rice; entrepreneurial activity is rare.

\section{- Aspect 6: Governance}

As shown elsewhere (Bryceson and Ross, 2020), the church dominates the governance of most aspects of village life in both Tonga and Solomon Islands. For example, at one marketplace in Marovo Lagoon, the market could not commence until prayers had been offered and the church bell tolled. Similarly, in Tonga, where church and chief are often one, markets would often need to await chiefly approval before they could start. In large regional and capital city markets, the role of the church is much less obvious. These markets are controlled by a city authority. Nevertheless, many market sellers would still await approval from their chief or church leader before making the journey to the marketplace. With the church and the chief having such a marked role in economic governance, the role of the villager as a member of the community significantly outweighs his/her role as a market seller. The results reinforce support for a conclusion that the informal nature of the social system and its governance are dominated by kinship and religion, rather than economics. 
Overarchingly, our findings emphasise that the economic situation in these societies is one of subsistence as identified by Sharma (2006), which is based on local socio-political frameworks. Cultural norms underpin day-to-day life and most businesses operate in an informal manner - all of which contributes to the longterm sustainability of the local community.

\section{Discussion and conclusions}

The research presented here has demonstrated that local food production and the occasional market activity practised by villagers in Tonga and Solomon Islands are firmly based in social, cultural and religious obligations that are embedded in the 'habitus of informality' that underpins the entire economic system. Informality generates inconsistency in supply and quality of all agrifood products; sellers are also producers; very few 'middlemen' or consolidators exist; and the end market is mostly local. Paradoxically, the local market is both predictable and unpredictable. Predictability comes from the lack of weekly product variability, with climate largely dictating what most sellers will bring to the market. Additionally, there is standard price setting, which is undertaken by market authorities and not by premium pricing. Prices only vary when producers are selling to kin or church contacts, and then price is generally set downwards - often to $\$ 0$ - because of kinship obligations. Unpredictability occurs with sellers able to vary product type from week to week, depending on what surplus has been produced in gardens. At times, markets have very little produce at all if gardens have not yielded any surplus. At these times, those desperate for much needed cash will sell fish or seaweed or fern leaves gathered from the natural resource base. This further adds to the unpredictability of the markets. In short, the local market is generally diffuse, with market sellers being driven to sell surpluses or local natural resource products, rather than to understand demand requirements.

Local players are clearly not keen to move from their informal production systems into a frontstage performance of sophisticated demand driven systems, because the habitus of informality meets resilient socio-cultural requirements and thus sustains the backstage performance of the village as a strong social institution, supported by cultural obligations. Consequently, there is neither a genuine desire, nor opportunity, for product specialisation. The backstage reality ensures that the traditional subsistence base of the local economy remains paramount.

Thus, we essentially agree with La Porta and Shleifer (2014: 120) that informal economic systems are 'too inefficient to survive in the formal sector and do not join it even when barriers to entry are eliminated' and we could conclude that a habitus of informality is thus not likely to be sustainable in the current demand driven, consumer orientated business world. However, Bonebeau et al. (1999) likened a company's and/or an industry's many individual parts to ants in an ant colony. They postulated that by focusing on these distinct entities at 'ground' level, the answers to facilitating a coordinated overall management / growth strategy could be developed from the 'bottom up', given that such ant colonies were well organised despite having no centralised 'top down' control. Our results in these small-scale agrifood systems strongly reflect this view. Small-scale societies have such a strong, underlying informal economic system at the grass roots level, to which the whole community is attached, that innovative strategies to development and growth that make use of a bottom-up structural information flow may be very effective in maintaining economic and market sustainability.

So where does this leave us in terms of understanding sustainability in these small-scale food systems? As indicated earlier, a classic TBL focuses attention on economic viability as the basis for sustainability. The research reported here demonstrates that economics are not necessarily the focus of the producers and sellers of food produce in Tonga and Solomon Islands where crops are produced primarily for self, kin, church and the village, not for the market. Sustainability in this context has its focus in the social sphere of TBL which we illustrate in Figure 3 as conceptually underpinning the whole TBL approach. 


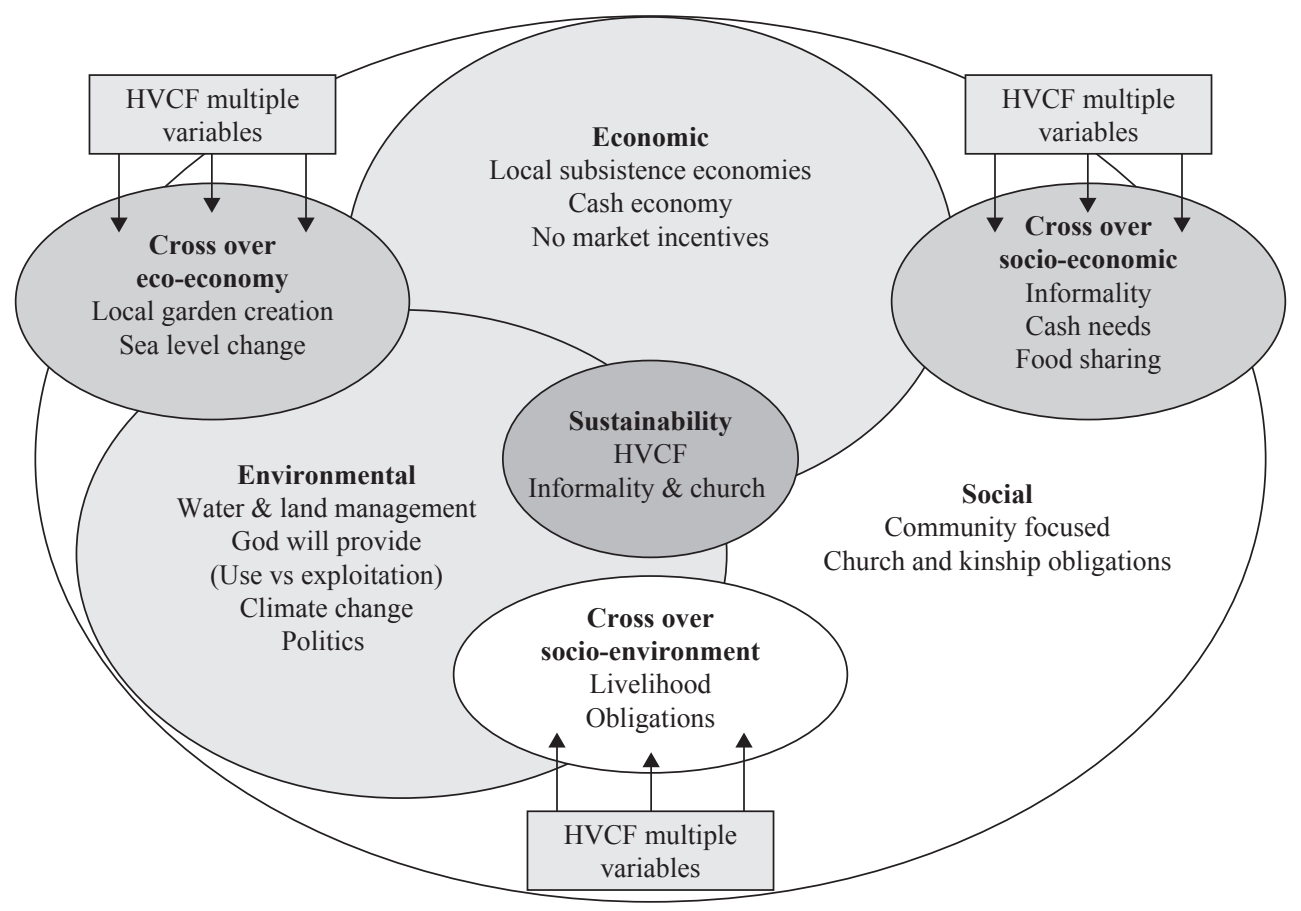

Figure 3. Illustration of a socially modified triple bottom line approach with Hybrid Value Chain Framework (HVCF) inputs where the social (people) component dominates.

We conclude that the habitus of informality that exits in small-scale societies is challenging for development in that it represents a highly complex socio-cultural and economic environment, but that it is also essential to any aid-generated initiatives and must be recognised and incorporated into aid packages that encourage long term, sustainable market growth and development in such societies. Further research on developing appropriate tools for investigating sustainability and peoples' understanding of what sustainability means and how that impacts livelihoods and 'doing business' is necessary. It is not just in small scale local agrifood chains that this needs investigation - as with many aspects of being involved in a chain of different actors doing business, the word 'sustainability' means different things to different components of every agrifood chain. As such, new survey instruments that address these differences need to be developed and deployed in order to understand underlying cultural and commercial mores for different sustainability behaviours.

\section{Acknowledgements}

The research was partially funded by a Small Research Grant from the PARDI (Pacific Agribusiness Research for Development Initiative) Program of the ACIAR (Australian Centre for International Agricultural Research) grants scheme. We acknowledge assistance of interviewees in Solomon Islands and Tonga; the research assistance provided by Milton Moloka and Anne Maeda in Solomon Islands; and the help of The Tonga Community Development Agency (TCDA) in Tonga.

\section{References}

Balbo, A.L., E. Gómez-Baggethun, M. Salpeteur, A. Puy, S. Biagetti and J. Scheffran. 2016. Resilience of small-scale societies: a view from drylands. Ecology and Society 21(2): 53. https://doi.org/10.5751/ ES-08327-210253

Béné, C., P. Oosterveer, L. Lamotte, I.D. Brouwer, S. De Haan, S.D. Prager, E.F. Talsma and C.K. Khoury. 2019. When food systems meet sustainability - current narratives and implications for actions. World Development 113: 116-130. 
Binder, C.R., G. Feola and J.K. Steinberger. 2010. Considering the normative, systemic and procedural dimensions in indicator-based sustainability assessments in agriculture. Environment Impact Assessment Review 3: 71-81. https://doi.org/10.1016/j.eiar.2009.06.002

Bonabeau, E., M. Dorigo and G. Theraulaz. 1999. Swarm intelligence: from natural to artificial systems. Oxford University Press, Oxford, UK.

Bourdieu, P. 1977. Outline of a theory of practice. Cambridge University Press, Cambridge, UK.

Bourdieu, P. 1986. The forms of capital. In: J.G. Richardson (ed.) Handbook of theory and research for the sociology of education. Greenward Press, New York, NY, USA, pp. 241-258.

Brundtland, G.H. 1987. Our common future. World Commission on Environment and Development document A/42/427. United Nations General Assembly, New York, NY, USA.

Bryceson, K.P. and A. Ross. 2019. Habitus of informality in small scale society agrifood chains - filling the knowledge gap using a socio-culturally focused value chain analysis tool. Journal of the Asia Pacific Economy 25(3): 545-570. https://doi.org/10.1080/13547860.2019.1670930

Bryceson, K.P. and A. Ross. 2020. Agrifood chains as complex systems and the role of informality in their sustainability in small scale societies. Sustainability 12: 6535.https://doi.org/10.3390/su12166535

Bryceson, K.P. and C.S. Smith. 2008. Abstraction and modelling of agri-food chains as complex decision making systems. In: M. Fritz, U. Rickert and G. Schieffer (eds.) EAAA Series on Systems Dynamics and Innovation in Food Networks. $110^{\text {th }}$ Seminar, February 18-22, 2008. Innsbruck-Igls, Austria, pp. $147-161$.

Cao, S., K. Bryceson and D. Hine. 2019. An ontology-based Baysian network modelling for supply chain risk propagation. Industrial Management \& Data Systems 119(8): 1691-1711. https://doi.org/10.1108/ imds-01-2019-0032

Cattaneo, O., G. Gereffi, S. Miroudot and D. Taglioni. 2013. Joining, upgrading and being competitive in global value chains: a strategic framework. Policy Research Working Paper No. WPS6406. World Bank Poverty Reduction and Economic Management Network, International Trade Department. World Bank, Washington, DC, USA.

Elayah, M. 2016. Lack of foreign aid effectiveness in developing countries between a hammer and an anvil. Contemporary Arab Affairs 9(1): 82-99. https://doi.org/10.1080/17550912.2015.1124519

Elkington, J. 1994. Towards the sustainable corporation: win-win-win business strategies for sustainable development. California Management Review 36: 90-100. https://doi.org/10.2307/41165746

Elkington, J. 2018. 25 years ago I coined the phrase triple bottom line. Here's why it's time to rethink it. Harvard Business Review, June 25, 2018. Available at: https://hbr.org/2018/06/25-years-ago-i-coinedthe-phrase-triple-bottom-line-heres-why-im-giving-up-on-it

Ericksen, P.J. 2008. Conceptualizing food systems for global environmental change research. Global. Environmental Change 18: 234-245.

Eyben, R. 2005. Donors' learning difficulties: results, relationships and responsibilities. Institute of Development Studies (IDS) Bulletin 36: 98-107.

Gamboa G., Z. Kovacic, M. Di Masso, S. Mingorría, T. Gomiero, M. Rivera-Ferré and M. Giampietro. 2016. The complexity of food systems: defining relevant attributes and indicators for the evaluation of food supply chains in Spain. Sustainability 8: 515-538. https://doi.org/10.3390/su8060515

Garriga, E. and D. Mele. 2004. Corporate social responsibility theories: mapping the territory. Journal of Business Ethics 53: 51-71.

Goffman, E. 1959. The presentation of self in everyday life. The Overlook Press, New York, NY, USA.

Haque, T.A. 2018. A 'good governance' paradox? Re-examining reform of economic institutions in postconflict contexts. Development Policy Centre, Discussion Paper 68. Australian National University, Canberra, Australia.

Harland C.M. 1996. Supply chain management: relationships, chains and networks. British Journal of Management 7(1): 63-80.

Hoffstaedter, G. and C. Roche. 2011. All the world's a stage: structure, agency and accountability in international aid. Journal of the Asia Pacific Economy 16(4): 529-543. https://doi.org/10.1080/135 47860.2011.610886

Ingram, J.S.I. 2011. A food systems approach to researching interactions between food security and global environmental change. Food Security 3: 417-431. 
La Porta, R. and A. Shleifer. 2014. Informality and development. Journal of Economic Perspectives 28(3): 109-126.

Lélé, S.M. 1991. Sustainable development: a critical review. World Development 19: 607-621. https://doi. org/10.1016/0305-750X(91)90197-P

McGuire, J., A. Sundgren and T. Schneeweis, 1988. Corporate social responsibility and firm financial performance. The Acadamy of Management Journal 31(4): 854-872.

Mosse, D. 2013. Adventures in Aidland: the anthropology of professionals in international development. Berghahn, New York, NY, USA.

Oxford Dictionary. 2020. Sustainability. Oxford University Press. Oxford, UK.

Peano, C., N. Tecco, E. Dansero, V. Girgenti and F. Sottile. 2015. Evaluating the sustainability in complex agri-food systems: the SAEMETH framework. Sustainability 7: 6721-6741. https://doi.org/10.3390/ su7066721

Ram, M., P. Edwards, T. Jones and M. Villares-Varela. 2017. From the informal economy to the meaning of informality: developing theory on firms and their workers. International Journal of Sociology and Social Policy 37(7-8): 361-373.

Ravenhill, J. 2014. Global value chains and development. Review of International Political Economy 21(1): 264-274. https://doi.org/10.1080/09692290.2013.858366

Reenberg, A.T., O. Birch-Thomsen, B. Mertz, B. Fog and S. Christiansen. 2008. Adaptation of human coping strategies in a small island society in the South West Pacific - 50 years of change in the coupled human-environment system on Bellona, Solomon Islands. Human Ecology 36(6): 807-819. https:// doi.org/10.1007/s10745-008-9199-9

Ross, A. and K. Bryceson, 2019. Traditional thinking: the impact of international aid on social structures and cultural traditions in agrifood chains in Tonga and Solomon Islands. Journal of the Asia Pacific Economy 24(3): 402-429.

Sharma, K.L. 2006. Food security in the South Pacific Island Countries with special reference to the Fiji Islands. Research Paper 2006/68, World Institute for Development Economics Research (UNUWIDER), Helsinki, Finland.

Smith, K., G. Lawrence, A. MacMahon, J. Muller and M. Brady. 2016. Resilience of long and short food chains: a case study of flooding in Queensland, Australia. Agriculture and Human Values 33: 45-60. https://doi.org/10.1007/s10460-015-9603-1

Surana, S., M. Kumara, M. Greaves and U.N. Raghavan. 2005. Supply-chain networks: a complex adaptive systems perspective. International Journal of Production Research 43(20): 4235-4265.

Susomrith, P. and Y. Suseno. 2017. Social capital and the social context of business networks. In: J. Nolan, C. Rowley and M. Warner (eds.) Business networks in East Asian capitalisms. Elsevier, Amsterdam, the Netherlands.

Tendall, D.M., J. Joerin, B. Kopainsky, P. Edwards, A. Shreck, Q.B. Le, P. Kruetli, M. Grant and J. Six. 2015. Food system resilience: defining the concept. Global Food Security 6: 17-23. https://doi. org/10.1016/j.gfs.2015.08.001

Thompson, J., E. Millstone, I. Scoones, A. Ely, F. Marshall, E. Shah and Stagl, S. 2007. Agri-food system dynamics: pathways to sustainability in an era of uncertainty. STEPS Working Paper 4, STEPS Centre, Brighton, UK.

Underhill, S.J.R., R. Stringer, K.P. Bryceson, B.C. Prasad and D. Shearer. 2010. The pacific agribusiness research for development initiative (PARDI): a novel approach to horticultural development in the pacific. Acta Horticulturae 921: 17-24. https://doi.org/10.17660/ActaHortic.2011.921.1

Viswanathan, M., S. Sridharan, R. Ritchie, S. Venugopal and K. Jung. 2012. Marketing interactions in subsistence marketplaces: a bottom-up approach to designing public policy. Journal of Public Policy \& Marketing 31(2): 159-177. https://doi.org/10.1509/jppm.11.049

Vorley, B. 2013. Meeting small-scale farmers in their markets: understanding and improving the institutions and governance of informal agrifood trade. International Institute for Environment and Development (IIED), London, UK.

Yin, R. 2003. Case study research: design and methods, $3^{\text {rd }}$ edition. Applied Social Research Methods Series 5. Sage Publications Inc., Thousand Oaks, CA, USA. 